\title{
Identification and B-lactam resistance in aquatic isolates of Enterobacter cloacae and their status in microbiota of Domica Cave in Slovak Karst (Slovakia)
}

\author{
Barbora Gaálová ${ }^{1}$, Alena Donauerová ${ }^{2}$, Milan $\operatorname{Seman}^{1}$, and Helena Bujdáková2* \\ ${ }^{1}$ Comenius University, Faculty of Natural Sciences, Department of Molecular Biology, Mlynska dolina B2, 84215 Bratislava, Slovakia \\ ${ }^{2}$ Comenius University, Faculty of Natural Sciences, Department of Microbiology and Virology, Mlynska dolina B2, 84215 Bratislava, Slovakia
}

\begin{abstract}
Domica Cave is located in the Slovak Karst National Park in southern Slovakia. Heterotrophic cultivable psychrophilic and mesophilic microbiota were confirmed to be prevalent in this cave. Escherichia coli was the most abundant bacterium, followed by Enterobacter species and Serrratia species. Enterobacter cloacae isolates belong to the group of faecal contaminants (coliforms) of concern in water. Their status in cave ecosystem is questionable, but we observed E. cloacae in water samples all years round suggesting an autochthonous origin. We were concerned with possible contamination of the cave water with resistant $E$. cloacae from animal farms located 2-3 km from the cave. We tested 36 aquatic isolates of $E$. cloacae from Domica Cave to $\beta$-lactam resistance. The majority of tested isolates were resistant to more antibiotics (from 3 to 10), 5 isolates were resistant to more than 10 antibiotics, and 1 isolate was resistant to ampicillin. Resistance to the broad spectrum of $\beta$-lactams correlated with resistance mechanisms due to an expression of $b / a_{\mathrm{TEM}} b / a_{\mathrm{SHV}}$ and $b / a_{\mathrm{CTX}-\mathrm{M}}$ genes. The majority of isolates possessed a combination of tested resistance genes. We assume a direct impact of long-term human agricultural activities in the area of the Domica Cave to the conserved microbiota of karst system.
\end{abstract}

Keywords: $\quad$ Domica Cave; karst water system; Enterobacter cloacae; $\beta$-lactam resistance Received 30 June 2013; Revised 15 January 2014; Accepted 16 January 2014

Citations: Gaálová B., Donauerová A., Seman M. and Bujdáková H. 2014. Identification and ß-lactam resistance in aquatic isolates of Enterobacter cloacae and their status in microbiota of Domica Cave in Slovak Karst (Slovakia). International Journal of Speleology, 43 (1), 69-77. Tampa, FL (USA) ISSN 0392-6672 http://dx.doi.org/10.5038/1827-806X.43.1.7

\section{INTRODUCTION}

In spite of extended research in microbiota of caves located in different sides of the world over the past 10-20 years, our knowledge has still been limited (Jurado et al., 2010; Saiz-Jimenez, 2012; Vanderwolf et al., 2013). Microorganisms play a significant role in cave ecosystems, mainly due to their contribution in building speleothems, circulation of matter in aphotic ecosystem and their participation in biotic interactions (Barton \& Northup, 2007; Jones, 2010; Bauermeister et al., 2012). There is a difference between natural endokarst communities of microorganisms, so called autochthonous microbiota and transient allochthonous microbiota (Farnleiter et al., 2005; Pronk et al., 2008). The ratio between both groups can change in regard to many stimuli like season and weather, rain events (Dussart-Baptista et al., 2003; Goldscheider et al., 2010), cave tourism (FernandezCortes et al., 2011; Saiz-Jimenez, 2012), or due to using chemical components to control lampenflora growth in show caves (Bastian et al., 2009). An important factor affecting protected locations is building villages or animal farms nearby which may be a source of pollution (Martinez, 2009). The karst system is extremely sensitive to infiltration with polluted water contaminated by bacteria or pharmacologically active substances (Brandon et al., 2010; Einsiedl et al., 2010; Morasch, 2013). Escherichia coli and total coliform bacteria including members of the genus Enterobacter are conventional indicators of microbial contamination (WHO, 2006). Antibiotics used in prevention and treatment of animal diseases, and to increase animal growth have still been one of the major factors of pollution despite the recommendation of the European Union on the prudent use of antibiotics and on a coordination between human and veterinary antibiotic policy (EFSA, 2010; Obeng et al., 2012; Harnisz, 2013). Prevalence of antibiotics in agriculture may result in violation of ecosystem with an impact to micro- and macrobiota located in these conserved biotopes due to a dissemination of bacteria carrying 
different resistance determinants (Wright et al. 2010, Eisenberg et al., 2011; Wellington et al., 2013).

Our research studied groundwater karst system of the Domica show cave (Fig. 1) located in the south of Slovakia in which resistant Enterobacter species (spp.) have been detected. Previous information about microbial composition of this cave suggested that members of the genus Enterobacter belong to the dominant mesophilic microbiota isolated from water (Seman \& Gaálová, 2009). Generally, among Enterobacter spp., Enterobacter cloacae has occupied a leader position as bacterium of an environmental origin as well as a source of human diseases (Baudart et al., 2011; Pavlovic et al., 2012). This species (sp.) has been frequently identified like nosocomial pathogen with a high ability to adopt and spread resistance against a variety of antibiotics (Mezzatesta et al., 2012; Radu et al., 2012). These bacteria have very often possessed resistance to $\beta$-lactams, the most frequently used antibiotics (Danziger \& Neuhauser, 2011; Page, 2012) due to TEM or SHV ESBLs (extended spectrum $\beta$-lactamases) production (Coque et al., 2008; Dhillon \& Clark, 2012; Korzniewska \& Harnisz, 2013), and CTX-M ESBLs have been identified more frequently as well (Livermore et al., 2007; D'Andrea et al., 2013).

This work represents an original and exclusive research documenting a total number of cultivable microorganisms and a spectrum of collected enterobacteria in the Domica Cave. Additionally, 3 animal farms are situated nearby this cave, so $\beta$-lactam resistance in selected $E$. cloacae originating from the cave water was investigated.

\section{DESCRIPTION OF DOMICA CAVE}

The Domica is a part of Domica-Baradla cave system on the Slovakian-Hungarian boundary. The length of Domica Cave in Slovakian side is $5,368 \mathrm{~m}$, whereas the whole system with Baradla is $25,564 \mathrm{~m}$ long. The protected area of the Domica Cave is 616,6892 ha. The main cave channel is created by underground stream Styx, with an older, dry cave level in fragments above it. The youngest phreatic level is also composed of fragments and it is situated about $20-47 \mathrm{~m}$ below the main active passage (Gaál, 2008). The underground waters of Styx and younger phreatic channels rise to the surface in Jósva Spring near Jósvafö Village in Hungary. The main part of the catchment area of Styx stream overlies in Slovakia and in past, it was polluted several times due to agriculture activities. Establishment of a protected area in the year 2005 improved this unfavorable state. The cave system was created in Triassic limestone but its development was strongly influenced by non-karstic rocks of old river cover (gravel, sand and clay), in its direct vicinity. Some occasional streams flow on this cover sinking into underground spaces through ponors at the limestone/gravel contact. These occasional streams create some lateral channels in the cave system ending with the Styx stream (e.g., Domický Brook in Slovakia and Little Baradla, Acheron stream and Retek branch in Hungary). The air temperature in the Domica Cave is between $9-10^{\circ} \mathrm{C}$. The Domica Cave is well-known as a wintering place for bats, site of rare underground invertebrates, and a famous locality of Neolithic man (Bella, 1997; Jakál et al., 2008).

\section{MATERIAL AND METHODS}

\section{Sample collection}

The water samples were seasonally collected aseptically into sterile $100 \mathrm{ml}$ dark glass bottles from 2007 to 2011 from various sites of the subterranean streams in Domica Cave (Fig. 1). The first sampling site was the groundwater stream Styx near Roman Spa (D1), the second was the Ponor of the Domicky

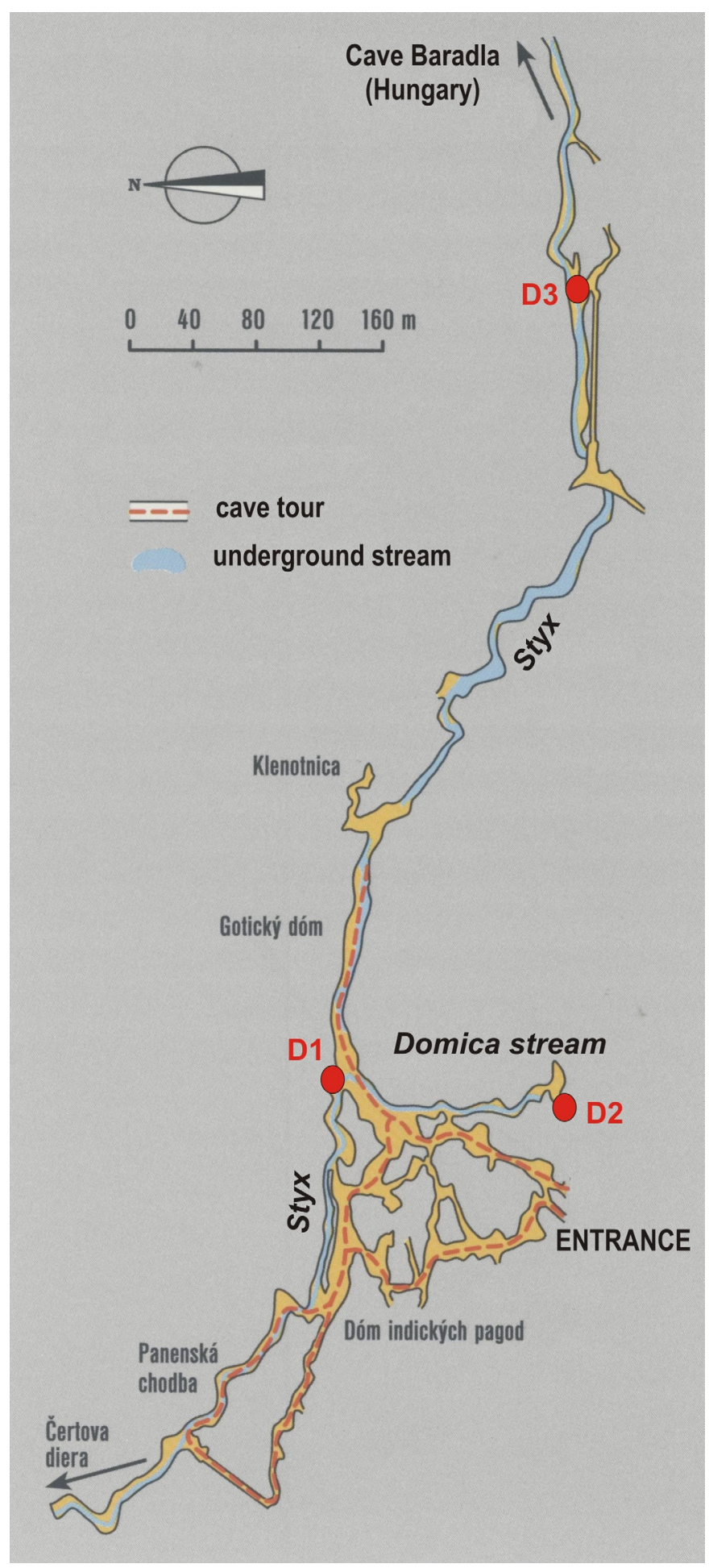

Fig. 1. The map of the Domica Cave with selected sampling sites. D1 - groundwater stream Styx near Roman Spa; D2 - the Ponor of Domický Brook, D3 - the Diamond Cruise (II. Cruise). 
Brook, surface brook after entering into the cave (D2), and the third sampling site was the Diamond Cruise (II. Cruise), mixed water of the Styx and Domicky Brook (D3). Samples were transferred in a portable refrigerator $\left(5-8^{\circ} \mathrm{C}\right)$ and processed within $24 \mathrm{~h}$ after collecting (according to ISO standard for microbiology analysis of water quality, EN ISO 19458, 2007).

\section{Cultivation of microorganisms}

One $\mathrm{ml}$ of each water sample was inoculated to Mueller-Hinton Agar (HiMedia, India). Colonies of microorganisms were formed at $22^{\circ} \mathrm{C}$ (psychrophilic microorganisms) for $72 \mathrm{~h}$ or at $36^{\circ} \mathrm{C}$ (mesophilic microorganisms) for $48 \mathrm{~h}$ according to Häusler, 1994. After incubation, the colony forming units (CFU) were counted.

\section{Identification of enterobacteria}

Bacteria were cultivated on MacConkey Agar (HiMedia, India) at $36^{\circ} \mathrm{C}$ for $48 \mathrm{~h}$. They were identified by the biochemical identification system ENTEROtest 24 with TNW Lite 6.5 program (Erba-Lachema, Czech Republic). Serratia marcescens CCM 303 and Enterobacter cloacae CCM 1903 were used as reference standard strains for verification of biochemical identification sets. Additionally, 6 reference strains of the genus Enterobacter. E. cloacae CCM 1903, E. aerogenes CCM 7797, E. amnigenus CCM 3430, E. cowanii CCM 7015, E. gergoviae CCM 3459, and E. asburiae CCM 4032 were used in the study. Reference strains were obtained from the Czech Collection of Microorganisms (CCM).

\section{DNA extraction}

All strains were grown on Mueller-Hinton Agar (HiMedia, India) at $37^{\circ} \mathrm{C}$ for $24 \mathrm{~h}$. One full loop of colonies was suspended in $300 \mu 1$ of sterile deionised water and boiled for $10 \mathrm{~min}$ at $95^{\circ} \mathrm{C}$. After centrifugation at $12,000 \mathrm{x}$ g for $8 \mathrm{~min}$ at $4^{\circ} \mathrm{C}$, the supernatants were recovered and $2 \mu \mathrm{l}$ was directly used as the template for PCR.

\section{tDNA and universal PCR, restriction with BstBI and DdeI enzymes}

For tDNA, specific set primers T3B (5'- AGG TCG CGG GTT CGA ATC C-3') and T5A (5'- AGT CCG GTG CTC TAA CCA ACT GAG-3') (Invitrogen, USA, Clementino et al., 2001) were selected. Universal primers for $16 \mathrm{~S}$ rRNA U1 (5 - CCA GCA GCC GCG GTA ATA CG-3') and U2 (5 - ATC GGY TAC CTT GTT ACG ACT TC-3’) (Invitrogen, USA, Lu et al., 2000) were used for PCR. The PCR reaction $(20 \mu \mathrm{l})$ contained $4 \mu \mathrm{l}$ of $5 \mathrm{x}$ HOT FIREPol Blend Master Mix (with 12.5 $\mathrm{mM} \mathrm{MgCl}_{2}$ ) (Solis BioDyne, Estonia), $0.4 \mu 1$ of relevant primers (all per 2 pmol), 13.2 $\mu$ of sterile deionised water, and $2 \mu 1$ of DNA template. Conditions of tDNA PCR were as follow: denaturation at $95^{\circ} \mathrm{C}$ for $12 \mathrm{~min}$, then denaturation at $94^{\circ} \mathrm{C}$ for $30 \mathrm{~s}$, annealing at $50^{\circ} \mathrm{C}$ for $30 \mathrm{~s}$, extension at $72^{\circ} \mathrm{C}$ for $2 \mathrm{~min}$ (35 cycles), and additional extension at $72^{\circ} \mathrm{C}$ for $10 \mathrm{~min}$. The program for universal PCR consisted of denaturation at $95^{\circ} \mathrm{C}$ for 12 min followed with denaturation at $94^{\circ} \mathrm{C}$ for 1 min, annealing at $55^{\circ} \mathrm{C}$ for $1 \mathrm{~min}$, extension at $72^{\circ} \mathrm{C}$ for $2 \mathrm{~min}$ (35 cycles), and additional extension at $72^{\circ} \mathrm{C}$ for $10 \mathrm{~min}$. The PCR products were used for restriction with BstBI (2500 U BMI Fermentas, Germany) and DdeI (500 U BMI Fermentas, Germany) enzymes. Restriction mix contained $0.2 \mu 1$ of BstBI enzyme or DdeI enzyme, $2 \mu$ of 10x Buffer Tango with BSA (MBI Fermentas, Germany), $12.8 \mu 1$ of sterile deionised water, and $5 \mu \mathrm{l}$ of PCR product. Restriction was performed in thermoblock MD-01 (Major Science, USA) at $37^{\circ} \mathrm{C}$ for $2 \mathrm{~h}$. Then $2 \mu \mathrm{l}$ of $6 \mathrm{x}$ DNA Loading Dye (MBI Fermentas, Germany) were added to stop the reaction. Ultra Power ${ }^{\mathrm{TM}}$ Nucleic Acid Stain (5 $\mu$ l) (BioTeke, China) was applied into gel during its preparation. A sample of $10 \mu 1$ of the PCR product (or restriction product) was loaded onto $1 \%$ agarose gel. Electrophoresis was performed at $100 \mathrm{~V}$ for $120 \mathrm{~min}$ in $1 \mathrm{x}$ TBE (Tris-borate-EDTA buffer, $\mathrm{pH}$ 8.3). For comparison, 100 bp Plus DNA Ladder Gene Ruler $^{\mathrm{TM}}$ (MBI Fermentas, Germany) was used. DNA was visualized with UV-transilluminator MUV21-312220 (Major Science, USA) at wavelength $254 \mathrm{~nm}$.

\section{Disk diffusion assay and Combination disk diffusion assay}

Assays were performed according to the recommendation of CLSI, M2-A10, 2009a, and CLSI, M100-S19, 2009b. Briefly; one loop of $24 \mathrm{~h}$ old culture was suspended in broth (Mueller-Hinton Broth, HiMedia) and incubated to log phase growth. The suspension was diluted in sterile water $(1: 1000)$ and then $100 \mu \mathrm{l}$ was inoculated on MHA plate. The disks containing antimicrobial agents were applied on plates within $15 \mathrm{~min}$ of inoculating. For disk diffusion assay, following antibiotics (Bio-Rad, France) were tested: ampicillin $(10 \mu \mathrm{g})$, carbenicillin (100 $\mu \mathrm{g})$, amoxycillin-clavulanic acid $(20 / 10 \mu \mathrm{g})$, ampicillinsulbactam $(10 / 10 \mu \mathrm{g})$, cefazolin $(30 \mu \mathrm{g})$, cefalotin (30 $\mu \mathrm{g})$, cefaclor $(30 \mu \mathrm{g})$, cefuroxime $(30 \mu \mathrm{g})$, cefoxitin (30 $\mu \mathrm{g})$, cefprozil (30 $\mu \mathrm{g})$, cefonicid (30 $\mu \mathrm{g})$, ceftazidime (30 $\mu \mathrm{g})$, ceftizoxime $(30 \mu \mathrm{g})$, and cefepime $(30 \mu \mathrm{g})$. Plates were incubated at $37^{\circ} \mathrm{C}$ for $18 \mathrm{~h}$ and the inhibition zones were measured. For combination disk diffusion assay, disks with cefotaxime $(30 \mu \mathrm{g})$, cefotaximeclavulanic acid $(30 / 10 \mu \mathrm{g})$, ceftazidime $(30 \mu \mathrm{g})$, and ceftazidime-clavulanic acid $(30 / 10 \mu \mathrm{g})$ were tested (Bio-Rad, France).

\section{PCR for detection of $b l a_{\mathrm{SHV}}, b l a_{\mathrm{TEM}}$, and $b l a_{\mathrm{CTX}-\mathrm{M}}$ genes}

For each type PCR, appropriate pairs of primers (Metabion, Germany) were selected: GRA1 (5'- ATG CGT TAT ATT CGC CTG TG-3') and GRA2 (5 - GTT AGT GTT GCC AGT GCT CG-3`) for detection of the bla $_{\mathrm{SHV}}$ gene (Babini \& Livermore, 2000); TEM-A (GTA TGG ATC CTC AAC ATT TCC GTG TCG) and TEM-B (ACC AAA GCT TAA TCA GTG AGG CA) for detection of the bla $_{\text {TEM }}$ gene (Stapleton et al., 1995); MA1 (ATG TGC AGY ACC AGT AA) and MA2 (ACC GCR ATA TGR TTG GT) for detection of the bla ${ }_{\text {Стх-м }}$ gene (Saladin et al., 2002). Each PCR reaction $(20 \mu \mathrm{l})$ consisted of 4 $\mu \mathrm{l}$ of 5x HOT FIREPol Blend Master Mix (with 12.5 $\mathrm{mM} \mathrm{MgCl}_{2}$ ) (Solis BioDyne, Estonia), per 2 pmol of appropriate primers, $13.2 \mu 1$ of sterile deionised water, and $2 \mu \mathrm{l}$ of DNA. The programs for every PCR were designed independently according to publications 
with mentioned primer sets. PCR products were visualized as described.

\section{RESULTS AND DISCUSSION}

Microorganisms are regular inhabitants of different niches including caves. The composition of cave microbiota is affected by many environmental factors independent of human activities, but also those ones directly associated with human impact like an import of microorganisms through mass tourism in show caves (Saiz-Jimenez, 2012). Another possible risk effect represents nearby animal farms because of groundwater contamination (Sapkota et al., 2007; Martinez, 2009). Our research studied a proportion of heterotrophic cultivable bacteria isolated from waters of the Domica Cave; it was mainly focused at diversity among enterobacteria, and resistance to $\beta$-lactams in Enterobacter cloacae, one of the dominant mesophilic bacterial species. In the period of 2007-2011, 17 sample collections were realized from 3 sampling sites (D1, D2, D3, Fig. 1) during the years 2008 - 2009 the water samples were collected seasonally. In the years 2007 - 2010 and in the year 2011, the samples were taken only in autumn and winter because of rainfall deficiency. The data confirmed two dominant groups of heterotrophic cultivable microbiota belonging to psychrophilic and mesophilic microorganisms that are able to survive at low temperature $\left(9-10^{\circ} \mathrm{C}\right)$ in cave during a year. Numbers of psychrophilic microorganisms ranged from $10^{2}$ to $10^{3} \mathrm{CFU} / \mathrm{ml}$ and numbers of mesophilic microorganisms ranged from $10^{1}$ to $10^{2} \mathrm{CFU} / \mathrm{ml}$. Both groups of microorganisms are widely distributed in the karst caves (Khyzniak et al., 2003; Semikolennykh et al., 2004). The majority of microorganisms were recovered in summer and spring, periods which are generally characterized by frequent rainfall or snow melt. From the hydrochemical point of view, the groundwater stream Styx near Roman Spa (D1) belongs to Ca$\mathrm{HCO}_{3}$ type, with dominant $\mathrm{HCO}_{3}$ anions and $\mathrm{Ca}^{2+}$ cations. The average daily temperature of the water is around $9.3^{\circ} \mathrm{C}$. The primary chemical composition of the Ponor of the Domicky Brook (D2) largely depends on quality of rainwaters. Water of the Ponor of the Domický Brook predominantly belongs to $\mathrm{Ca}-\mathrm{HCO}_{3}$ type, or less $\mathrm{Ca}-\mathrm{Mg}-\mathrm{HCO}_{3}, \mathrm{Ca}-\mathrm{HCO}_{3}-\mathrm{SO}_{4}$ or $\mathrm{Ca}-\mathrm{Mg}-$ $\mathrm{HCO}_{3}-\mathrm{SO}_{4}$ type, with dominant $\mathrm{Ca}^{2+}$ and $\mathrm{Mg}^{2+}$ cations and $\mathrm{HCO}_{3}^{-}$anions, less $\mathrm{SO}_{4}{ }^{2-}, \mathrm{Cl}^{-}$and $\mathrm{NO}_{3}{ }^{-}$anions. The average daily temperature of the water in this location is around $9.8^{\circ} \mathrm{C}$. For the water from Diamond Cruise (II. Cruise, D3), there are dominant $\mathrm{HCO}_{3}, \mathrm{Ca}^{2+}$ and $\mathrm{Mg}^{2+}$ ions, which determine the $\mathrm{Ca}-\mathrm{HCO}_{3}$ type (Gazda, 1974; Haviarová et al., 2010). The average daily temperature of the water is around $10^{\circ} \mathrm{C}$. The water $\mathrm{pH}$ of all sampling sites is slightly alcaline. Haviarova et al. (2010) summarized more chemical parameters and microbiological indicators of water quality in the Domica Cave water system. The problem concerning water contamination has also been described from the hydrochemical and microbiological point of view in other related caves in Slovak karst: Krásnohorská Cave, Diviačia Chasm and Attilova Chasm (Motyka et al., 2005), Milada Cave (Haviarová et al., 2011), SilicaGombacek cave system (Haviarová et al., 2012), and in Demänovský Cave System, Low Tatra Mountains (Motyka et al., 2005).

Enterobacteriaceae is a group of mesophilic bacteria associated with environmental pollution. Many studies from cave environments are attended to this group, mainly in regard to an association with faecal contamination of soil, karstic waters or cave walls (Personé et al., 2004; Lavoie \& Northup, 2006; Pronk et al., 2008). In this study, 285 isolates of enterobacteria were identified among mesophilic microorganisms (Fig. 2) with Escherichia coli (112 isolates) as the most abundant bacterium. This microorganism was collected mainly in summer of 2008 and 2009 that probably resulted from the several rainfalls during those years. E. coli belongs to the coliform bacteria which are monitored in waters as faecal indicators of water pollution (WHO, 2006). The second most dominant Enterobacteriaceae isolated belonged in the Enterobacter genus (53 isolates). E. cloacae (36), E. amnigenus (5), E. dissolvens (4), enteric group 69 (4), E. gergoviae (3), and E. cancerogenus (1) were identified.

According to Leclerc et al. (1997), Enterobacter spp. have been included in allochthonous microbiota like E. coli in both drinking and ground waters. However, in this research, Enterobacter spp. were not found to be seasonable present in the water samples collected from all sampling sites. This observation suggests an autochthonous origin of collected Enterobacter spp., as these bacteria were recovered regardless of sampling season and occurred in various areas of cave.

Concerning this information, it seemed to be interesting to search for possible origin and resistance profile of E. cloacaefrom Domica Cave. In the immediate area of Domica Cave, there are 3 animal farms located within 2-3 km (Fig. 3), thus probable contamination from these farms might be assumed. In the 1970s, more than 500 cows were kept in animal farms Dlhá Ves and Kečovo villages. During that time, veterinary drugs containing the combinations of amoxicilline with clavulanic acid were served on a mass scale to animals. At present, the livestock in Dlhá Ves has been stopped. Ferdi-Ranch (horse and cow farm between Dlhá Ves and Domica) still has cradled 75 pieces of black cattle and Kečovo village has several cows and sheep which are pastured on the watershed of the Domica Cave. Until now, commercially available preparations containing amoxicillin with clavulanic acid has been still applied, but in a limited amount and only for therapeutic reasons (personal communication with local veterinarian).

Thirty six E. cloacae showing the same profile as the reference strain E. cloacae CCM 1903 in ENTEROtest 24 were selected for the resistance study; 9 isolates were collected from the site D1, 12 from the site D2 and 15 from the site D3. Prior to the study of $\beta$-lactam resistance, identification of $E$. cloacae was completed by molecular biology: the universal PCR with restriction by BstBI and DdeI enzymes and the tDNA PCR. Universal PCR amplified fragment of the gene encoding 16S rRNA was used for restriction analysis 


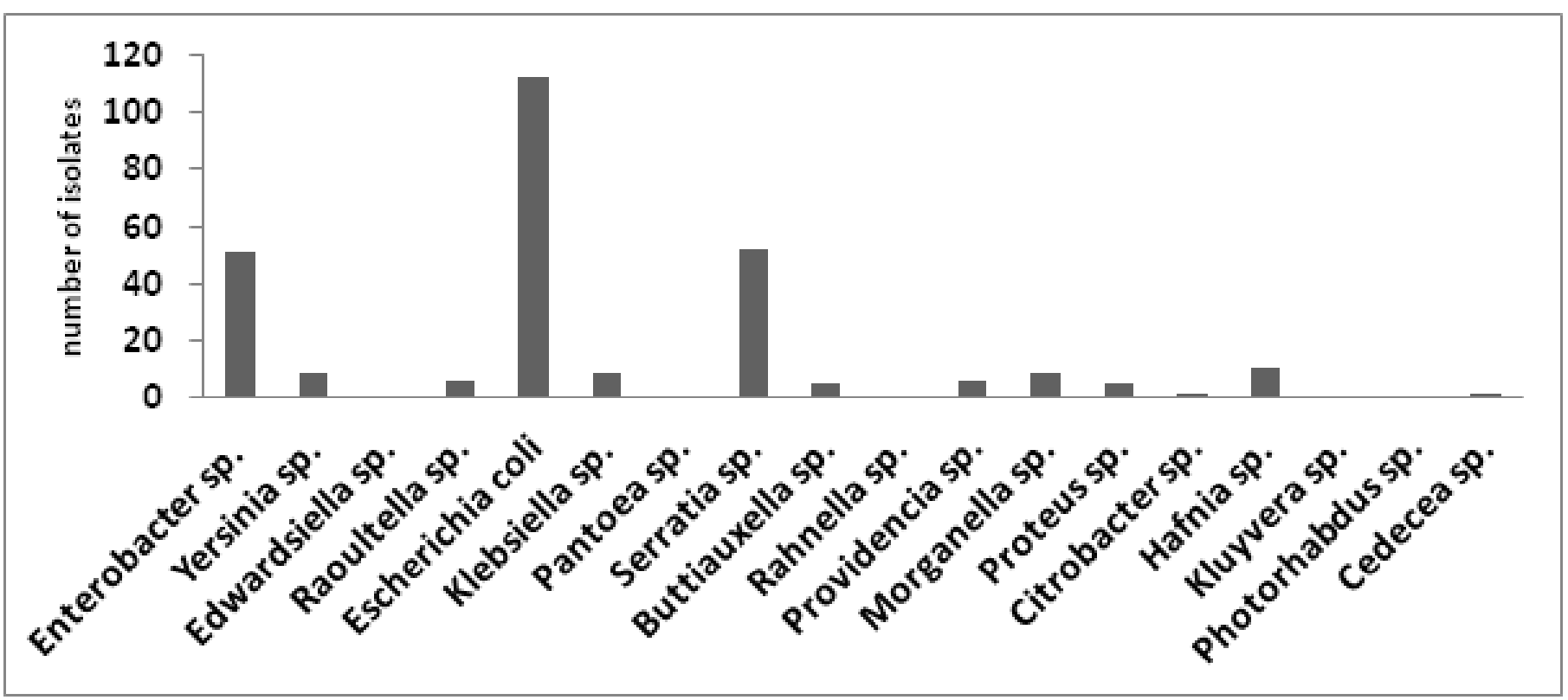

Fig. 2. Spectrum of isolated enterobacteria from the Domica Cave.

in order to discriminate the genus Enterobacter from the other bacterial genera (Lu et al., 2000). All our tested isolates showed the same profile like the majority of the reference Enterobacter strains (Fig. 4). Only E. cowanii CCM 7015 showed a different profile. The tDNA PCR method (Clementino et al., 2001) allows distinguishing some spp. of Enterobacter like E. cowanii, E. aerogenes, E. gergoviae, E. asburiae, E. amnigenus, and E. cloacae (Fig. 5). Both methods confirmed that selected E. cloacae were correctly identified. All these isolates were submitted for the study of $\beta$-lactam resistance.

At present, an increasing prevalence of the problematic clinical isolates of $E$. cloacae with the broad spectrum $\beta$-lactam resistance has been documented (Jaskulski et al., 2013). Among bla genes, bla $a_{\text {TEM }}$ has been identified as the most frequently occurring type

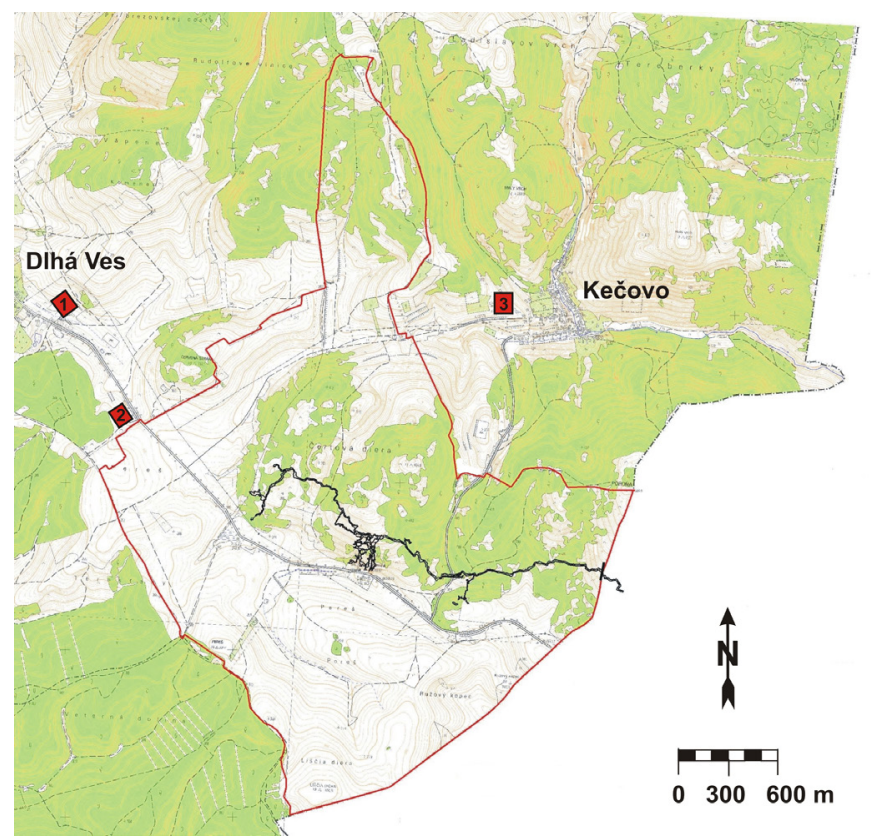

Fig. 3. Map of catchment area of the Domica Cave (the cave is marked with black color, red line is the surface of protected cave area. Red rectangles characterizes agricultural areas: 1. Agricultural cooperation in Dlhá Ves village, 2. "Ferdi ranch" (horse farm), 3. Agricultural cooperation in Kečovo village. of gene encoding $\beta$-lactamases (Jaskulski et al., 2013).

All E. cloacae were tested for susceptibility/ resistance to penicillin and $\beta$-lactam antibiotics and the results are summarized in Tab. 1. There was only 1 isolate resistant to ampicillin. Other isolates were resistant to more antibiotics (mostly from 3 to 10) and 5 isolates were resistant to more than 10 antibiotics. We did not observed differences in susceptibility of tested isolates in regard to isolation site. Additionally, 18 isolates were detected as the ESBL producers by combination disks assay when ceftazidime and combination of ceftazidime-clavulanic acid was used, and 1 isolate when cefotaxime and combination of cefotaxime-clavulanic acid was applied. These results suggested the presence of bla genes. Therefore, another aim of our work was

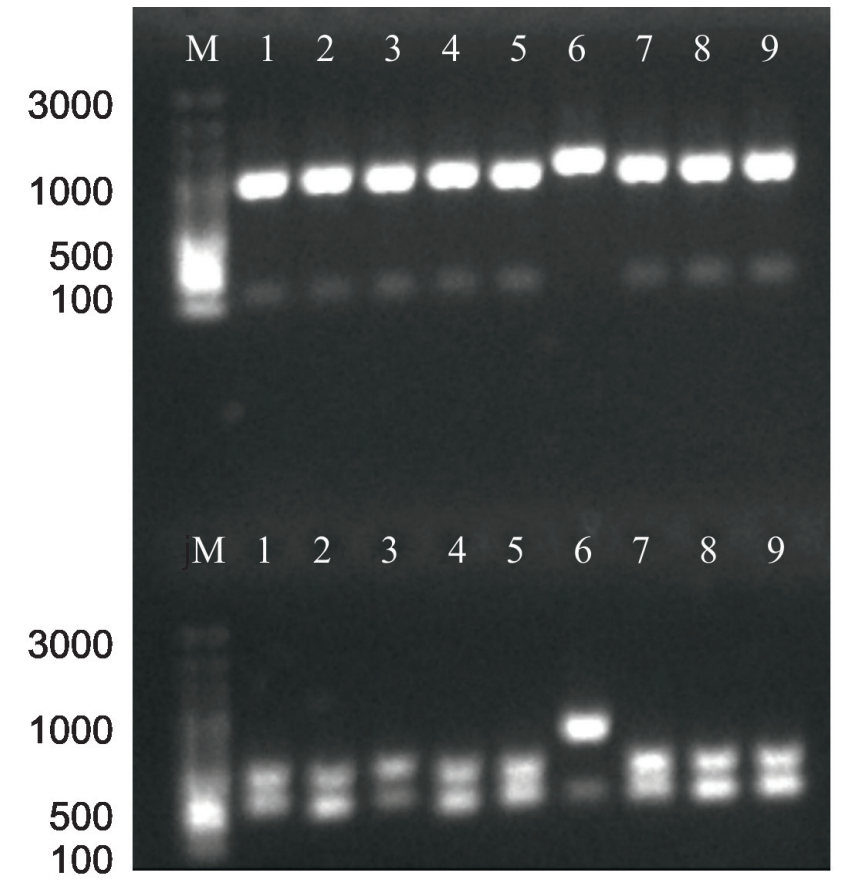

Fig. 4. Electrophoresis of the universal PCR (upper line) and the restriction with BstBI and Ddel enzymes (bottom line) M- DNA ladder 100 bp Plus, 1. E. cloacae, 2. E. aerogenes, 3. E. gergoviae, 4. E. asburiae, 5. E. amnigenus, 6. E. cowanii, 7 - 9. aquatic isolates of $E$. cloacae. 
Table 1. Testing susceptibility to antibiotics in 36 aquatic isolates of Enterobacter cloacae.

\begin{tabular}{|c|c|c|c|c|c|c|c|c|c|c|c|c|c|c|}
\hline & \multicolumn{2}{|c|}{ penicillin } & \multicolumn{2}{|c|}{$\begin{array}{l}\text { penicillin with } \\
\text { inhibitors } \\
\text { of } \beta \text {-lactamases }\end{array}$} & \multicolumn{2}{|c|}{ cephalosporin } & \multicolumn{2}{|l|}{ 2. gen. } & \multirow[b]{2}{*}{ FOX } & \multirow[b]{2}{*}{$\mathrm{CPR}$} & \multirow[b]{2}{*}{$\mathrm{CID}$} & \multicolumn{2}{|l|}{ 3. gen. } & \multirow{2}{*}{$\begin{array}{l}4 . \\
\text { gen. } \\
\text { FEP }\end{array}$} \\
\hline & $\mathrm{AM}$ & $\mathrm{CB}$ & AMC & AMS & $c z$ & CF & CEC & CXM & & & & $C A Z$ & $\mathrm{ClZ}$ & \\
\hline $\begin{array}{l}\text { No. of resistant isolates/ } \\
\% \text { of resistant isolates }\end{array}$ & $34 / 94$ & $26 / 72$ & $21 / 58$ & $9 / 25$ & $26 / 72$ & $31 / 86$ & $14 / 39$ & $10 / 28$ & $23 / 64$ & $18 / 50$ & $29 / 81$ & $18 / 50$ & $9 / 25$ & $9 / 25$ \\
\hline
\end{tabular}

AM - ampicillin $(10 \mu \mathrm{g})$; CB - carbenicillin $(100 \mu \mathrm{g}) ; \mathbf{A M C}$ - amoxicillin-clavulanic acid $(20 / 10 \mu \mathrm{g}) ; \mathbf{A M S ~ - ~}$ ampicillin-sulbactam (10/10 $\mu \mathrm{g})$; CZ - cefazolin (30 $\mu \mathrm{g})$; CF - cefalotin (30 $\mu \mathrm{g})$; CEC - cefaklor (30 $\mu \mathrm{g})$; CXM cefuroxim $(30 \mu \mathrm{g})$; FOX - cefoxitin $(30 \mu \mathrm{g})$; CPR - cefprozil $(30 \mu \mathrm{g})$; CID - cefonicid (30 $\mu \mathrm{g})$; CAZ - ceftazidime $(30 \mu \mathrm{g}) ; \mathbf{C I Z}$ - ceftizoxime $(30 \mu \mathrm{g})$; FEP - cefepime $(30 \mu \mathrm{g})$

to detect bla genes $\left(b l a_{\mathrm{TEM}}, b l a_{\mathrm{SHV}}, b l a_{\mathrm{CTX}-\mathrm{M}}\right)$ encoding TEM-, SHV- and CTX-M type $\beta$-lactamases. Genes for $b l a_{\mathrm{TEM}}$ were detected in 8 isolates, genes for $b l a_{\mathrm{SHV}}$ were determined in 7 isolates, and genes for $b l a_{\mathrm{CTX}-\mathrm{M}}$ encoding CTX-M type $\beta$-lactamases were confirmed in 9 isolates. Three isolates possessed a combination of $b l a_{\mathrm{SHV}}$ and $b l a_{\text {Стх-м }}$ genes and 2 isolates expressed all three types of bla genes tested. There were not detected any bla genes in 15 isolates. The occurrence of bla genes in selected aquatic isolates is presented in the Fig.6. Some previous reports pointed to the phenomenon of the incidence of antibiotic resistance determinants in bacteria originating from caves or extreme biotopes (Brown \& Balkwill, 2009, Thaller et al., 2010). Moreover, Bhullar et al. (2012) in their study concerning macrolide resistance suggested that antibiotic resistance is natural and ancient. In contrast, Kemper (2008) concluded that using antibiotics in animals results in occurrence of resistant bacteria in soil and waters. In this relation, there is a question whether resistance to $\beta$-lactams of the $3^{\text {rd }}$ and $4^{\text {th }}$ cephalosporin generation could be naturally present in cave microbiota. We implicate observed resistance in E. cloacae isolated from the Domica Cave with the long-term activities of neighboring animal farms and

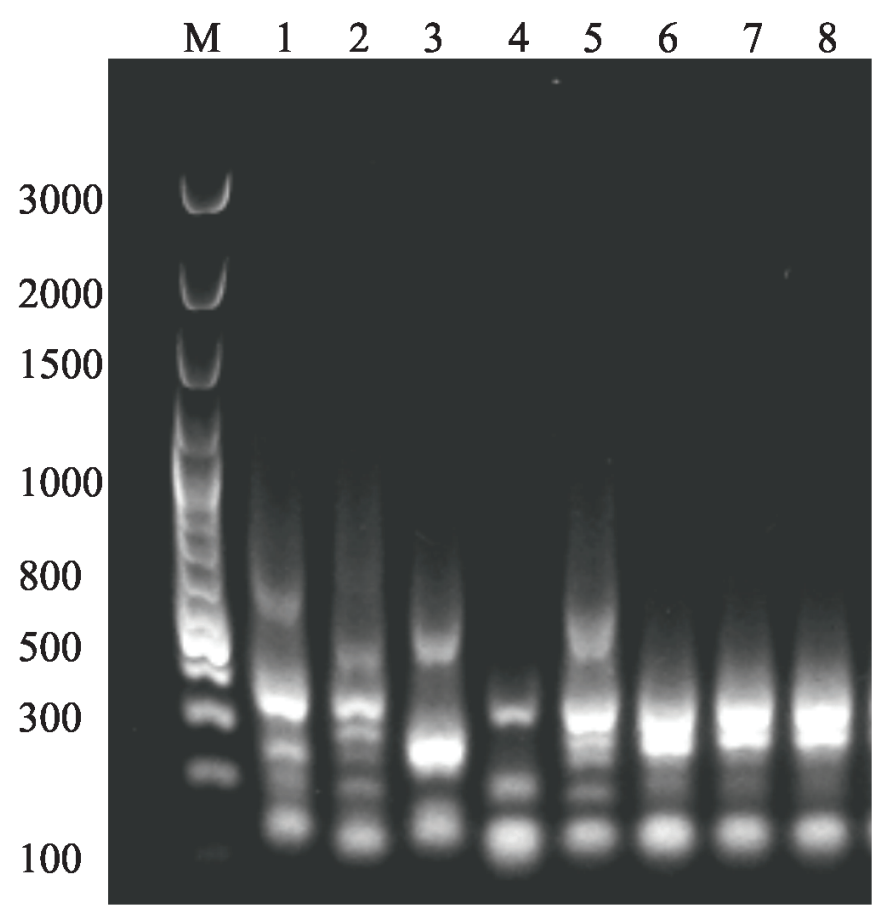

Fig. 5. Electrophoresis of the tDNA PCR M- DNA ladder 100 bp Plus, 1. E. cowanii, 2. E. aerogenes, 3. E. gergoviae, 4. E. asburiae, 5. E. amnigenus, 6. E. cloacae, 7 - 8. aquatic E. cloacae isolates continuous antibiotic pressure, despite the fact, that current animal pharmacy use is more restricted in agreement with the recommendation of the European Union. Moreover, as E. cloacae is a characteristic member of the transient allochthonous microbiota and our enterobacteria were isolated regardless of season, it might be expected that they were imported to the cave by underground water during the rains.

\section{CONCLUSIONS}

The results of our investigation revealed the prevalence of heterotrophic cultivable microbiota from psychrophilic and mesophilic microorganisms in the Domica Cave. The dominant bacterium was E. coli followed by the genus Enterobacter from enterobacteria. Showed $\beta$-lactam resistance, especially, to the $3^{\text {rd }}$ and $4^{\text {th }}$ cephalosporin generations and resistance mechanisms in isolates of E. cloacae obtained from waters of the Domica Cave indicated an external source of resistance gene contamination. The

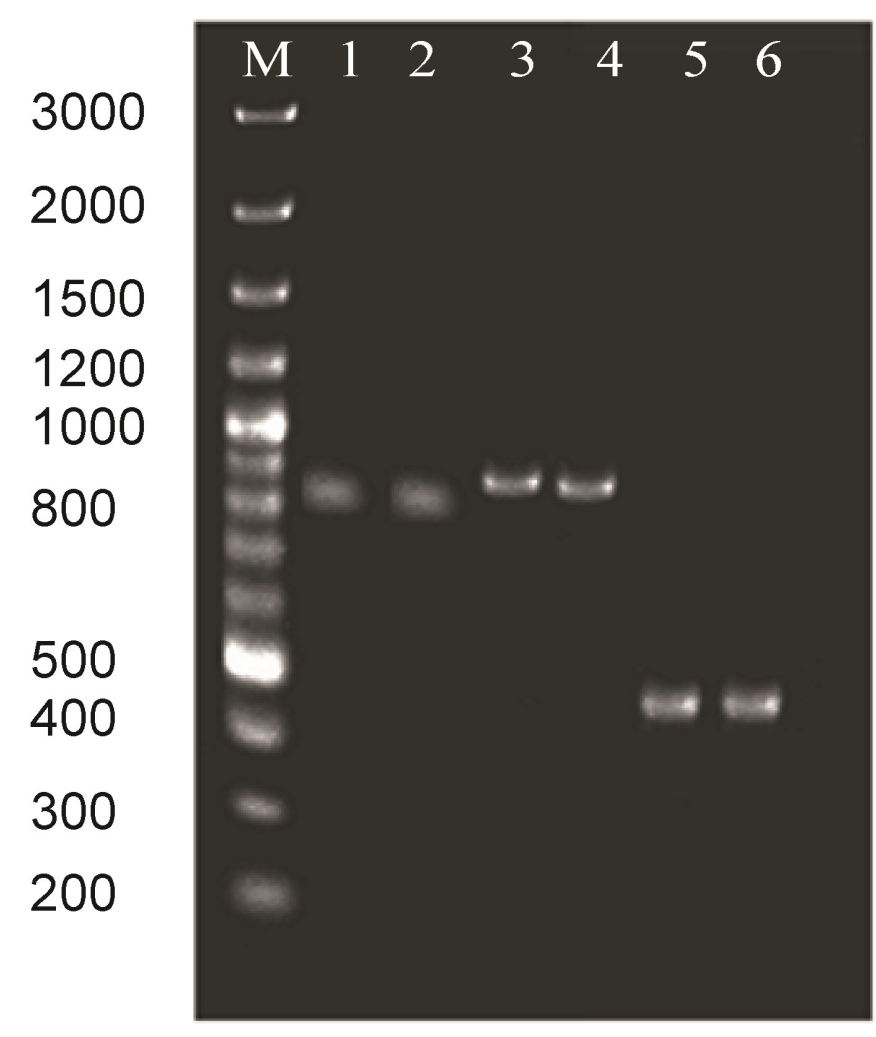

Fig. 6. Electrophoresis of the PCR detection of bla genes in aquatic $E$. cloacae M - DNA ladder 100 bp Plus, 1-2 gene bla ${ }_{\mathrm{TEM}}$, 3-4 gene bla $a_{\mathrm{SHV}}$, 5-6 gene bla ${ }_{\mathrm{CTX}-\mathrm{M}}$ 
group of resistance determinants, found also in this work, is usually located on mobile elements and the antibiotic pressure contributes significantly to their horizontal transfer among bacteria. Observation of the resistant $E$. cloacae isolates in protected area of the Domica Cave suggests close relationship between quality of surface (including ground and waters) nearby the cave and its aquatic ecosystem. Taken together, determined resistance in aquatic $E$. cloacae isolated from Domica Cave can be an example of the anthropogenic pressure that might affect natural microbiota of conserved ecosystems.

\section{ACKNOWLEDGEMENT}

This research was supported by the grants of VEGA 1/0117/09, VEGA 1/0899/12, and VEGA 1/0966/ 12 from the Ministry of Education, Science, Research and Sport of the Slovak Republic. This article is also the result of the project implementation: 'Production of biologically active agents based on recombinant proteins' (ITMS 26240220048) supported by the Research and Development Operational Program funded by the ERDF. The authors thank the Slovak Caves Administration in Liptovský Mikuláš, Slovak Republic for the opportunity of sampling the Domica Cave.

\section{REFERENCES}

Babini G.S. \& Livermore D.M., 2000 - Are SHV betalactamases universal in Klebsiella pneumoniae? Antimicrobial Agents and Chemotherapy, 44: 2230. http://dx.doi.org/10.1128/AAC.44.8.2230-2230.2000

Barton H.A. \& Northup D.E., 2007 - Geomicrobiology in cave environments: past, current and future perspectives. Journal of Cave and Karst Studies, 69: 163-178.

Bastian F., Alabouvette C., Jurado V. \& Saiz-Jimenez C., 2009 - Impact of biocide treatments on the bacterial communities of the Lascaux Cave. Naturwissenschaften, 96: 863-868.

http://dx.doi.org/10.1007/s00114-009-0540-y

Baudart J., Robyns A., Peuchet S., Drocourt J.L. \& Lebaron P., 2011 - Sensitive counting of viable Enterobacteriaceae in seawaters and relationship with faecal indicators. Journal of Microbiological Methods, 84: 482-485. http://dx.doi.org/10.1016/j.mimet.2011.01.015

Bella P., 1997 - Show caves in Slovakia. Knižničné centrum, Žilina, 62 p.

Bhullar K., Waglechner N., Pawlowski A., Koteva K., Banks E.D., Johnston M.D., Barton H.A. \& Wright G.D., 2012 - Antibiotic resistance is prevalent in an isolated cave microbiome. PLoS ONE, 7: e34953. http://dx.doi.org/10.1371/journal.pone.0034953

Brown M.G. \& Balkwill D.L., 2009 - Antibiotic resistance in bacteria isolated from the deep terrestrial subsurface. Microbial Ecology, 57: 484-493. http://dx.doi.org/10.1007/s00248-008-9431-6

Clementino M.M., de Filippis I., Nascimento C.R., Branquinho R.C.L. \& Martins O.B., 2001 - PCR analyses of tRNA intergenic spacer, 16S-23S internal transcribed spacer, and randomly amplified polymorphic DNA reveal inter-and intraspecific relationships of Enterobacter cloacae strains. Journal of Clinical Microbiology, 39: 3865-3870. http://dx.doi.org/10.1128/JCM.39.11.3865-3870.2001

Clinical and Laboratory Standards Institute (CLSI), 2009a Performance Standards for Antimicrobial Susceptibility Testing. Approved Standard M2-A10, PA, USA.
Clinical and Laboratory Standards Institute (CLSI), 2009b Performance Standards for Antimicrobial Susceptibility Testing. Approved Standard M100-S19, PA, USA.

Coque T.M., Baquero F. \& Canton R., 2008 - Increasing prevalence of ESBL-producing Enterobacteriaceae in Europe. Eurosurveillance, 13: 19-29.

D'Andrea M.M., Arena F., Pallecchi L. \& Rossolini G.M., 2013 - CTX-M-type $\beta$-lactamases: A successful story of antibiotic resistence. International Journal of Medical Microbiology, 303: 305-317.

http://dx.doi.org/10.1016/j.ijmm.2013.02.008

Danziger L.H. \& Neuhauser M., 2011 - Beta-Lactam antibiotic. In: Piscitelli S.C. Rodvold K.A. \& Pai M.P. (Eds.) - Drug Interactions in Infectious Diseases. Springer Science: 203-242.

Dhillon R.H.-P. \& Clark J., 2012 - ESBLs: A clear and present danger? Critical Care Research and Practice. Hindawi Publishing Corporation: $11 \mathrm{p}$.

Dussart-Baptista L., Massei N., Dupont J.-P. \& Jouenne T., 2003 - Transfer of bacteria-contaminated particles in a karst aquifer: evolution of contaminated materials from a sinkhole to a spring. Journal of Hydrology, 284: 285-295. http://dx.doi.org/10.1016/j.jhydrol.2003.08.007

EFSA, 2010 - The community summary report on antimicrobial resistance in zoonotic and indicator bacteria from animals and food in the European Union in 2004-2007: EFSA Journal, European Food Safety Authority, 8: 1-306.

Einsiedl F., Radke M. \& Maloszewski P., 2010 Occurrence and transport of pharmaceuticals in a karst groundwater system affected by domestic wastewater treatment plants. Journal of Contaminant Hydrology, 117: 26-36.

http://dx.doi.org/10.1016/j.jconhyd.2010.05.008

Eisenberg J.N.S., Goldstick J., Cevallos W., Trueba G., Levy K., Scott J., Percha B., Segovia R., Ponce K., Hubbard A., Marrs C., Foxman B., Smith D.L. \& Trostle J., 2011 - In-roads to the spread of antibiotic resistance: regional patterns of microbial transmission in northern coastal Ecuador. Journal of the Royal Society Interface, 9: 1029-39. http://dx.doi.org/10.1098/rsif.2011.0499

EN ISO 19458, 2007 - Water quality. Sampling for microbiological analysis. Water Research Institute, Bratislava.

Farnleitner A.H., Wilhartitz I., Ryzinska G., Kirschner A.K.T., Stadler H., Burtscher M.M., Hornek R., Szewzyk U., Herndl G. \& Mach R.L., 2005 - Bacterial dynamics in spring water of alpine karst aquifers indicates the presence of stable autochthonous microbial endokarst communities. Environmental Microbiology, 7: 1248-1259. http://dx.doi.org/10.1111/j.1462-2920.2005.00810.x

Fernandez-Cortes A., Cuezva S., Sanchez-Moral S., Cañaveras J.C., Porca E., Jurado V., Martin-Sanchez P.M. \& Saiz-Jimenez C., 2011 - Detection of human-induced environmental disturbances in a show cave. Environmental Science and Pollution Research, 18: 1037-1045. http://dx.doi.org/10.1007/s11356-011-0513-5

Gaál L., 2008 - Geodynamika a vývoj jaskýň Slovenského krasu. Liptovský Mikuláš, 166 p.

Gazda S., 1974 - Chemizmus podzemných vôd Západných Karpát a jeho genetická klasifikácia. In: B. Leško (Ed.) - Materiály z III. celoslovenskej geologickej konferencie, II. Čast'. Slovenský geologický úrad, Bratislava: 43-50.

Goldscheider N., Pronk M. \& Zopfi J., 2010 - New insights into the transport of sediments and microorganisms in karst groundwater. Geologia Croatica, 63: 137-142. http://dx.doi.org/10.4154/gc.2010.10

Harnisz M., 2013 - Total resistance of native bacteria as an indicator of changes in the water environment. Environmental Pollution, 174: 85-92. http://dx.doi.org/10.1016/j.envpol.2012.11.005 
Haviarová D., Flaková R., Seman M., Ženišová Z., 2010 Formovanie chemického zloženia vôd v jaskyni Domica. Podzemná voda, 16: 54-72.

Haviarová D., Flaková R., Ženišová Z., Seman M., 2011 - Chemické zloženie a mikrobiologické vlastnosti krasových vôd jaskyne Milada a jej podzemného hydrologického systému (Silická planina, Slovenský kras). Podzemna Voda, 17: 34-51.

Haviarová D., Flaková R., Seman M., Gaálová B., Ženišová Z., 2012 - Chemické zloženie a mikrobiologické vlastnosti krasových vôd Silicko-Gombaseckého jaskynného systému (Silická planina, Slovenský kras). Aragonit, 17: 3-14.

Häusler J., 1994 - Mikrobiologické kultivační metody kontroly jakosti vod. Ministerstvo zemědelství ČR, Praha: $164 \mathrm{p}$.

Hose L.D., Palmer A.N., Palmer M.V., Northup D.E., Boston P.J. \& Duchene H.R., 2000 - Microbiology and geochemistry in a hydrogen-sulphide-rich karst environment. Chemical Geology, 169: 399-423. http://dx.doi.org/10.1016/S0009-2541(00)00217-5

Hsu M.J. \& Agoramoorthy G., 2001 - Occurrence and diversity of thermophilous soil microfungi in forest and cave ecosystems of Taiwan. Fungal Diversity, 7: 27-33.

Jakál J., Bella P., Gaál L., Haviarová D., Hlaváč, J., Kováč L., Lalkovič M., Soják M. \& Zelinka J., 2008 - Caves of the World Heritage in Slovakia. Knižničné centrum, Žilina, 168 p.

Jaskulski M.R., Medeiros B.C., Borges J.V., Zalewsky R., Fonseca M.E., Marinowic D.R., Rocha M.P., Nodari P. \& Machado D.C, 2013 - Assessment of extendedspectrum $\beta$-lactamase, KPC carbapenemase and porin resistance mechanisms in clinical samples of Klebsiella pneumoniae and Enterobacter spp. International Journal of Antimicrobial Agents, 42: 76-79. http://dx.doi.org/10.1016/j.ijantimicag.2013.03.009

Jones B., 2010 - Microbes in caves: agents of calcite corrosion and precipitation. Geological Society, London, Special Publications, 336: 7-30.

http://dx.doi.org/10.1144/SP336.2

Jurado V., Laiz L., Rodriguez-Nava V., Boiron P., Hermosin B., Sanchez-Moral S. \& Saiz-Jimenez C., 2010 - Pathogenic and opportunistic microorganisms in caves. International Journal of Speleology, 39: 15-24. http://dx.doi.org/10.5038/1827-806X.39.1.2

Kemper N., 2008 - Veterinary antibiotics in the aquatic and terrestrial environment. Ecological Indicators, 8: 1-13. http://dx.doi.org/10.1016/j.ecolind.2007.06.002

Khizhnyak S.V., Tausheva I.V., Berezikova A.A., Nesterenko E.V. \& Rogozin D.Y, 2003 - Psychrophilic and psychrotolerant heterotrophic microorganisms of Middle Siberian karst cavities. Russian Journal of Ecology, 34: 231-235. http://dx.doi.org/10.1023/A:1024537513439

Korzeniewska E. \& Harnisz M., 2013 - Beta-lactamaseproducing Enterobacteriaceae in hospital effluents. Journal of Environmental Management, 123: 1-7. http://dx.doi.org/10.1016/j.jenvman.2013.03.024

Lavoie K.H. \& Northup D.E., 2006 - Bacteria as indicators of human impact in caves. In: Rea G.T. (Ed.) - 7th National Cave and Karst Management Symposium, Proceedings. NY: NICKMS Steering Committee, Albany: 40-47.

Leclerc H., Francalanci C. \& Papini E., 1997 - Indicatori atteriologici e controllo di qualita delle acqe minerali naturali. Biologia Ambientale, 6: 227-228.

Livermore D.M., Canton R., Gniadkowski M., Nordmann P., Rossolini G.M., Arlet G., Ayala J., Coque T.M., Kern-Zdanowicz I., Luzzaro F., Poirel L. \& Woodford N., 2007 - CTX-M: changing the face of ESBLs in Europe. Journal of Antimicrobial Chemotherapy, 59: 165-174. http://dx.doi.org/10.1093/jac/dkl483
Lu J.-J., Perng C.-L., Lee S.-Y. \& Wan C.-C., 2000 Use of PCR with universal primers and restriction endonuclease digestions for detection and identification of common bacterial pathogens in cerebrospinal fluid. Journal of Clinical Microbiology, 38: 2076-2080.

Martinez J.L., 2009 - Environmental pollution by antibiotics and by antibiotic resistance determinants. Environmental Pollution, 157: 2893-2902.

http://dx.doi.org/10.1016/j.envpol.2009.05.051

Mezzatesta M.L., Gona F. \& Stefani S., 2012 - Enterobacter cloacae complex: clinical impact and emerging antibiotic resistance. Future Microbiology, 7: 887-902. http://dx.doi.org/10.2217/fmb.12.61

Morasch B., 2013 - Occurrence and dynamics of micropollutants in a karst aquifer. Environmental Pollution, 173: 133-137.

http://dx.doi.org/10.1016/j.envpol.2012.10.014

Motyka J., Gradziński M., Bella P., Holúbek P., 2005 - Chemistry of waters from selected caves in Slovakia - a reconnaissance study. Environmental Geology, 48: 682-692. http://dx.doi.org/10.1007/s00254-005-0006-2

Obeng A.S., Rickard H., Ndi O., Sexton M. \& Barton M., 2012 - Antibiotic resistance, phylogenetic grouping and virulence potential of Escherichia coli isolated from the faeces of intensively farmed and free range poultry. Veterinary Microbiology, 154: 305-315. http://dx.doi.org/10.1016/j.vetmic.2011.07.010

Page M.G.P., 2012 - Beta - lactam antibiotics. In: Dougherty T.J. \& Pucci M.J. (Eds.) - Antibiotic Discovery and Development. Springer Science: 79-117.

Pavlovic M., Konrad R., Iwobi A.N., Sing A., Busch U. \& Huber I., 2012 - A dual approach employing MALDITOF MS and real-time PCR for fast species identification within the Enterobacter cloacae complex. FEMS Microbiology Letters, 328: 46-53. http://dx.doi.org/10.1111/j.1574-6968.2011.02479.x

Personné J.C., Poty F., Mahler B.J., Krogue C., 2004 Colonization by aerobic bacteria in karst: Laboratory and in situ experiments. Groundwater, 42: 526-533. http://dx.doi.org/10.1111/j.1745-6584.2004.tb02621.x

Pronk M., Goldscheider N. \& Zopfi J., 2008 - Microbial communities in karst groundwater and their potentional use for biomonitoring. Journal of Hydrogeology, 17: 37-48. http:/ /dx.doi.org/10.1007/s10040-008-0350-x

Radu G., Stefan M.L. \& Idomir M., 2012 - The spectrum of infections and the resistance to antibiotics of Enterobacter species. Bulletin of the Transilvania University of Brasov Series VI: Medical Sciences, 5: 51-56.

Saiz-Jimenez C., 2012 - Microbiological and environmental issues in show caves. World Journal of Microbiology and Biotechnology, 28: 2453-2464. http://dx.doi.org/10.1007/s11274-012-1070-x

Saladin M., Cao V.T. \& Lambert T. 2002 - Diversity of $C T X-M$ b-lactamases and their promoter regions from Enterobacteriaceae isolated in three Parisian hospitals. FEMS Microbiology Letters, 209: 161-168. http://dx.doi.org/10.1111/j.1574-6968.2002.tb11126.x Sapkota A.R., Curriero F.C., Gibson K.E. \& Schwab K.J., 2007 - Antibiotic-resistant Enterococci and faecal indicators in surface water and groundwater impacted by a concentrated swine feeding operation. Environmental Health Perspectives, 115: 1040-1045. http://dx.doi.org/10.1289/ehp.9770

Seman M. \& Gaálová B., 2009 - Enterobakteriálna mikrobiota jaskynných vôd Silickej planiny. Slovenský kras, 47: 283-290.

Semikolennykh A.A., Ivanova A.E. \& Dobrovol'skaya T.G., 2004 - Microbial communities in gypsum caves and soils of karst landscapes in Arkhangelsk Oblast. Eurasian Soil Science, 37: 191-198. 
Stapleton P., Wu P.-J., King A., Shannon K., French G. \& Phillips I., 1995 - Incidence and mechanisms of resistance to the combination of amoxicillin and clavulanic acid in Escherichia coli. Antimicrobial Agents and Chemotherapy, 39: 2478-2483. http://dx.doi.org/10.1128/AAC.39.11.2478

Thaller M.C., Migliore L., Marquez C., Tapia W., Cedeno V., Rossolini G.M. \& Gentile G., 2010 - Tracking acquired antibiotic resistance in commensal bacteria of Galápagos land iguanas: No Man, no resistance. PLoS ONE 5: e8989. http://dx.doi.org/10.1371/journal.pone.0008989

Vanderwolf K.J., Malloch D., McAlpine D.F. \& Forbes G.J., 2013 - A world review of fungi, yeasts, and slime molds in caves. International Journal of Speleology, 42: 77-96. http://dx.doi.org/10.5038/1827-806X.42.1.9
Wellington E.M.H., Boxall A.B.A., Cross P., Feil E.J., Gaze W.H., Hawkey P.M., Johnson-Rollings A.S., Jones D.L., Lee N.M., Otten W., Thomas Ch.M. \& Williams A.P., 2013 - The role of the natural environment in the emergence of antibiotic resistance in Gram-negative bacteria. Lancet Infectious Diseases, 13: 155-65. http://dx.doi.org/10.1016/S1473-3099(12)70317-1

Wright G.D., 2010 - Antibiotic resistance in the environment - a link to the clinic? Current Opinion in Microbiology, 13: 589-594.

http://dx.doi.org/10.1016/j.mib.2010.08.005

WHO, 2006 Guidelines for Drinking-water Quality. World Health Organization Press. Switzerland. 